\title{
The presence of geogenically saline waters in the area of salt dome Rogóźno (central Poland)
}

\author{
Michał Górecki, Maciej Ziułkiewicz \\ University of Lodz, Faculty of Geographical Sciences, Laboratory of Geology; ul. Narutowicza 88, 90-139 Łódź, Poland; \\ e-mail:michal.gorecki@geo.uni.lodz.pl, maciej.ziulkiewicz@geo.uni.lodz.pl
}

(c) 2016 Authors. This is an open access publication, which can be used, distributed and reproduced in any medium according to the Creative Commons CC-BY 4.0 License requiring that the original work has been properly cited.

Received: 13 June 2016; accepted: 22 September 2016

\begin{abstract}
Rogóźno salt dome is one of the most recognizable diapirs in the Polish Lowland. Despite its shallow occurrence depth, increased salinity has not been detected in surface water. The presented hydrogeochemical research aimed at determining if there is the presence of increased geogenical salinity in the groundwater and shallow water. Increased geogenical salinity has not been detected in the Moszczenica River and the Czerniawka River, but were displayed in the Moszczenica River valley in the specific electrical conductivity (SEC) spatial distribution. Hydrogeochemical research indicated the presence of a higher mineralized water ascent in the north-eastern part of the dome. The presence of mixing of saline waters around the dome with fresh waters was determined. Ionic composition and hydrochemical indexes of waters sampled from different levels indicate that the saline structure is not completely isolated from surrounding waters. The dome structure is in contact with water from Upper Jurassic formation which influences the final water composition. Active anthropogenic processes partly mask the influences of geogenic salinity in the study area.
\end{abstract}

Keywords: Rogóźno salt dome, geogenical saline waters, hydrochemical indexes, the Moszczenica River

\section{INTRODUCTION}

Late Permian (Zechstein) salt deposits in Central Poland occur as domes, pillows, walls and diapirs, with a height of up to $7 \mathrm{~km}$ (Czapowski \& Bukowski 2012). Elastic salt masses, due to local disturbances in overburden, started moving towards the surface in the Upper Trias (Tarka 1992). The dome in Rogóźno is one of the diapirs in the Łódzkie voivodeship which completely broke through Upper Mesozoic formations (Fig. 1) (Stelmaszczyk 1972, Czapowski \& Bukowski 2012). Although it was recognized as one of the biggest salt domes of the Polish Lowlands (Tarka 1992), it has not yet been effectively recognized in geological terms (Czapowski \& Bukowski 2009).

Natural leakage of saline waters has been observed in shallow areas of saline formations (e.g. in Inowrocław or Ciechocinek - see Tarka 1992,
Jodłowski 1997). The presence of saline waters and salt brewing in the area of Łęczyca and Solca Wielka the Łódzkie voivodeship have been dated as early as the $13^{\text {th }}$ century (Fig. 1) (Jodłowski 1977), and continued in Solca Wielka and Pełczyska until the $18^{\text {th }}$ century (Kolago 1965). Natural leakage of saline waters in these areas has also been observed in contemporary times. Intensive settlement and highly-developed metallurgical and milling activity was documented in the Iron Age and Middle Ages in the Moszczenica River valley, which is the biggest river flowing over the central part of the dome. Pottery, cinders and metallurgical products, as well as remains of mills and smithies were found, for example in Gieczno, Rogóźno, Besiekierz (Fig. 1) (Kamiński 1993). The first information about bigger towns located in the dome area comes from the period between the $14^{\text {th }}$ and $16^{\text {th }}$ century (Dylik 1948, Tynenski et al. 2007). There 
is no evidence of the use of saline water in thearea of dome, both in the archeological material and historical documents. Currently, there is no natural flow of saline waters in this area as well.

Soil chemical features also provide evidence of being influenced by salinity from saline diapirs. Typically saline soil is not common in the Rogóźno area. In the Łódzkie voivodeship it is present only in the previously described areas of saline natural flows around Łęczyca, Pełczyska and Solca Wielka (Czerwiński 1996, Hulisz 2007a, 2007b).

Halophytes, which are plants growing in waters of high salinity, confirm higher soil salinity. $\mathrm{Nu}-$ merous areas of halophytes were present in the areas of Łęczyca and Ozorków (Fig. 1) until the second half of the $20^{\text {th }}$ century. Currently, the smaller presence of halophytes is preserved around Pełczyska (Kucharski 2009, Mróz 2010). The presence of saline areas with halophytes in the salt dome area was recognized only in the 60 's of $20^{\text {th }}$ century around Rogóźno and Gieczno. Its presence was, most likely, a short-term occurrence related to drilling projects conducted in the area at that time (Jaworski 1964). The flow of drilling fluids and saline waters could have occurred along poorly insulated drilling holes. The effect of the salt dome on the chemical composition of local water has been documented over the saline structure of Uścikowo (Prochazka 1970), and in the area of Rogóźno in the 50's and 60's (Jaworski 1964).
The aim of this research, apart from recognizing chemical features of groundwater in the Rogóźno area, was to analyze the spatial variability of surface water chemistry over the saline structure. This type of surface water analysis has not yet been conducted on saline structures. Based on the results, an attempt was made to establish whether saline water from the dome area could have been mixed with groundwater and surface water. The Moszczenica River valley located over the salt dome, along with surrounding hydrographic features (ponds, ditches, oxbow lakes) provide very good conditions for conducting such analyses.

\section{GEOLOGICAL SETTINGS}

Rogóźno salt dome is located in the Kuyavian-Pomeranian anticlinorium. It was formed similiarly to the Łódź sinclinorium - as a result of folding during older phases of Alpine orogeny and halotectonics (Turkowska 2001). The Rogóźno diapir is the center of the anticlinal structure which is surrounded by Mesozoic structures (Fig. 1). The dome borders Jurassic structures from the northeast, whereas from the south-west it borders Cretaceous formations. The anticline of Rogóźno continues in a SE direction, where in the core there is a sequence of embankments around the dome.

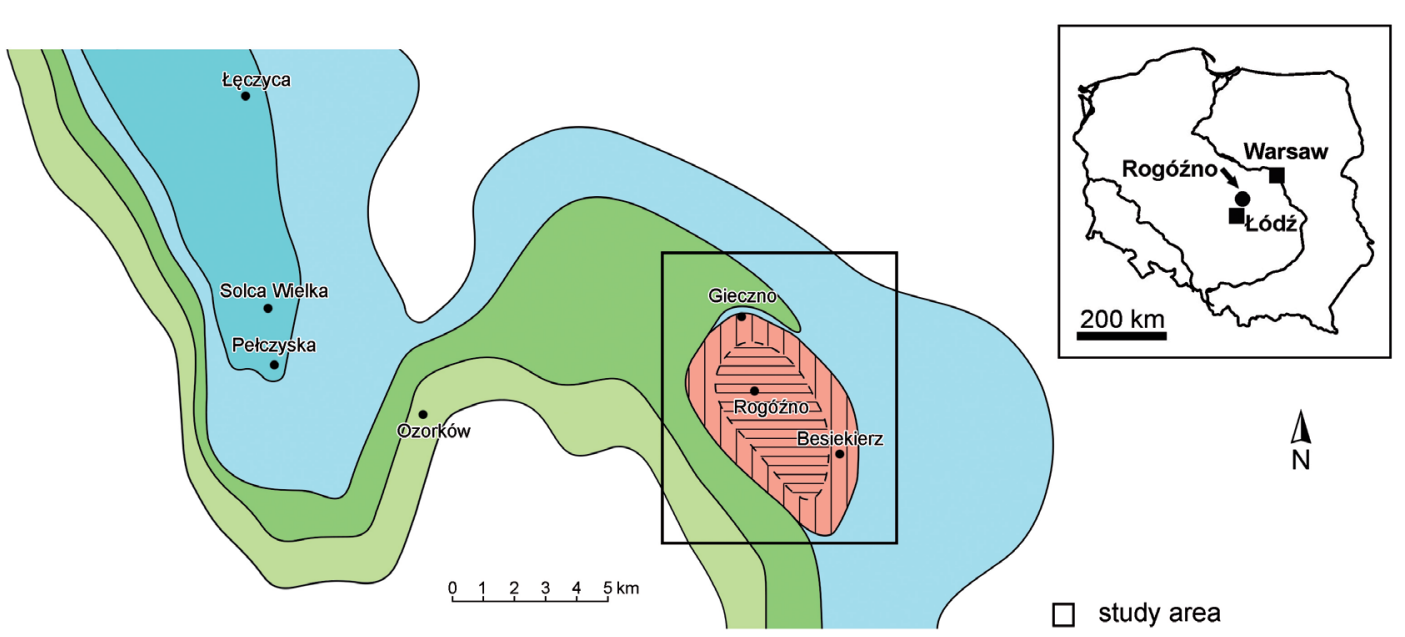

Lower-Middle Albian and Upper Cretaceous

Lower Creataceous (Valanginian-Lower Albian)

Upper Jurassic

Middle Jurassic Late Permian (Zechstein) cap of clay-gypsum cap of gypsum-anhydrite

Fig. 1. Geological map of Rogóźno and surrounding areas (after Marek 1957; simplified) 
In the plan view, the dome has an ellipsis-like shape, with a longer axis extending in the NWSW direction which is almost along the anticlinorium of Central Poland (Stelmaszczyk 1972). Rock salt in Rogóźno is composed of $97.8 \%$ of $\mathrm{NaCl}$; estimated rock salt resources to the maximum depth of $1000 \mathrm{~m}$ have been calculated at 8.6 trillion tons (Czapowski, on-line). The saline structure has a volume of around $120 \mathrm{~km}^{3}$ (Tarka 1992).

The thickness of the cap over the salt dome Rogóźno varies from $13 \mathrm{~m}$ in the northern part to $286 \mathrm{~m}$ in the south-eastern part (Stelmaszczyk 1972). Gypsum-anhydrite residuum was found in the central part, whereas loam and gypsum were found on its borders (Jaworski 1962). In the gypsum-anhydrite part, karst processes developed greatly. Karstification of the cap already occurred, most probably in the younger Tertiary. It is evidenced by the discontinuous layers of Eocene lignite present in only some of the sinkholes. Also, layers of Miocene lignite are discontinuous and they are only present in a few more significant depressions. It is evidence that the karstification of the cap was not completed in the Tertiary, but also continued in Pleistocene and may also have continued to occur in modern times. The process of the karstification of the cap contributed to the surface modification of the glacial till of the Warta. The deep buried forms and present valley of the Moszczenica River are related to karst processes taking place in the gypsum-anhydrite cap, especially in its central part (Kamiński 1993). There is a co-dependancy observed between the course of river valley and lowering in ceiling of Tertiary residuum. It is possible that deep and narrow erosive indentations in clay are related to karst lowering in the dome cap, repeated in the following geological periods (Kamiński 1993). Aragonite, a mineral rarely present in Poland and which has never been found in any saline residue of Polish Lowlands, was found in Rogóźno. Aragonite is, most probably, evidence of gypsum leaching (Jaworski 1962); after all, the process of leaching is especially intense in the environment reach in saline waters (Pazdro \& Kozerski 1990).

Cenozoic residue, which is present over the loam-gypsum alluvium, includes formations from the Paleogene, Neogene and Quaternary. The thickness of formations, previously classified as Tertiary, greatly varies in the cap basin; with the bottom of the formation being more diversified than formation top (Klatkowa 1993). Quaternary residues cover continuously the entire area with a layer of variable thickness (Turkowska 2001). The Quaternary residue thickness over the dome also varies greatly. Such diversity of thickness is a reflection of the elevation variability of the Tertiary top, and more levelled present topographic surface. Additionally, xenolithes, floes of Tertiary formations, marlstones and chalky limestones are among the Quaternary formations. They are most commonly present in areas of intensive glaciotectonic disturbances (Klatkowa 1993).

Mesozoic formations protect the salt pillar from dissolution. The contact between the salt and Mesozoic residue is strictly tectonic. There is a fault-flexure dislocation along the south and south-western border of the dome. It cuts and covers Mesozoic formations (from Trias to Lower Cretaceous-Valanginian). The dislocation zone on the east border of the dome is slightly lower. Residues of Upper Jurassic are in discordant contact with Zechstein formations, starting from Kimmeridgian (Stelmaszczyk 1972). The Jurassic is represented by the Late Jurassic limestones. There are Quarternary outcrops of Upper Jurassic limestones (Klatkowa 1993) in the Gieczno and Besiekierz area (the eastern and northern side of the dome). Late Jurassic limestones on the western side of the diapir are covered with the overhang of loam-gypsum cap and a thin layer of Lower Cretaceous which was only detected on the western and southern border of the dome (Stelmaszczyk 1972).

\section{HYDROGEOLOGICAL AND HYDROLOGICAL SETTINGS}

Intense tectonic, saline, glaciotectonic disturbances or karstification occuring in the area of the salt dome contribute to a complicated circulation system of groundwater flow. In some areas, groundwater flow of highly-mineralized water from deeper aquifers is displayed in the near-surface water flow system. There is a local, direct contact between aquifer Quaternary formation with Tertiary sands in Gieczno area (Miocene and possibly older) (Stelmaszczyk 1972). Water from Quaternary and Tertiary aquifers in the Rogóźno area are so interconnected that they might be considered to be one Miocene-Quaternary aquifer. 




Fig. 2. Documentation map of Rogóźno region 




Fig. 3. Area of possible ascent of groundwater from Tertiary formation against the system of hydroisobaths of the first deep Quaternary level 
Contact between this aquifer and water from Permian formation (Dokumentacja..., 2002) is probable. The Miocene level, connected with sands separating layers of lignite from different eras had, most probably, a hydraulic contact with a salt deposit (Stelmaszczyk 1972) connects with groundwater from the Permian formation. Groundwater around the dome (Permian system) may be accumulated in voids and fractures between the saline water table and a dense gypsum cap. The gypsum cap is, most likely, not always in direct contact with the saline water table and it creates a ceiling above washed-out parts of the salt dome. Frequently the higher part of residuum occurs as chaotic debris of gypsum and anhydrite with residues of salt, gypsum marlstone and loam. Such rubble, containing many empty voids, can be partially or completely filled with eluvial silt up before it becomes a compact rock mass. Saline water can be accumulated when these voids are completely filled with sediment (Szaniawski 1963). There is lateral contact between water from Upper Jurassic aquifer and saline water from Zechstein aquifer behind the northern and north-western border of the dome (Meszczyński \& Szczerbicka 2002). The high temperature of water from the Upper Jurassic aquifer indicates flow system from a greater depth that eventually accumulates in Jurassic limestones. Because of the neighboring salt dome, limestones were piled, disturbed tectonically and cracked. Covered with an impermeable loam-gypsum cap, they became a suitable reservoir for accumulating warm water flowing from below (Stelmaszczyk 1972).

The analysis of the Quaternary and Tertiary hydroisobaths is indicated in areas of Władysławów and Lorenki potential ascent zone (Figs. 2, 3) (Górecki 2015).

The Moszczenica River serves as a draining base level of shallow aquifer flow systems. Aquifers, present in Quaternary formations, form a local water circulation system while deeper aquifers (Tertiary and Upper Jurassic) form a regional system draining to the Bzura River valley on WNW from the dome (Bierkowska \& Blaszczyk 1989).

Moszczenica is the biggest river draining the northern part of the Łódź Hills. It is $56 \mathrm{~km}$ long and is a tributary of the Bzura River. Czerniaw$\mathrm{ka}$, its biggest tributary, flows into the Moszczenica River in the Rogóźno area (Fig. 2). Moszczenica
River and Czerniawka River are characterized with moderetaly developed nival regime which, in this area, is characterized by balanced groundwater and surface flow components in total outflow (Jokiel 2004). The highest flow in these rivers is noted at the turn of March and April, and the lowest at the turn of September and October (Maksymiuk 2001).

A little over 1/3 of the Moszczenica River length and over $1 / 2$ of the Czerniawka River lenght are located in the area of salt dome Rogóźno. Apart from Moszczenica and Czerniawka rivers, there are nameless surface streams in the area, with the total length of about $3 \mathrm{~km}$. In the dome area, the density of river system is relatively higher and amounts to about $0.579 \mathrm{~km} \cdot \mathrm{km}^{-2}$ (Szaniawski 1963), which means it is similar to the maximum amount in Central Poland $-0.6 \mathrm{~km} \cdot \mathrm{km}^{-2}$ (Jokiel 2004).

\section{METHODOLOGY OF FIELD RESEARCH ON SURFACE WATERS}

The analysis of hydrochemical conditions around the Rogóźno salt dome was conducted in selected observation points on the following rivers: the Moszczenica River, the Czerniawka River and their tributaries. Selection of sample-control points was performed strictly according to Inspectorate of Environmental Protection regulations (Gołębiowska et al. 1994), taking into consideration specificity of local conditions. 14 water samples were collected: seven from the Moszczenica River, two from the Czerniawka River and one of each of the tributaries (Fig. 2, Tab. 1). Water temperature (T), $\mathrm{pH}$ and SEC were measured at every point. Additionally, water levels $(H)$ were monitored in the gauge station of the Institute of Meteorology and Water Management in Moszczenica-Gieczno.

Other hydrographic features in Moszczenica River valley include oxbow lakes and mires, and artificial ponds and ditches. Spatial distribution of SEC was used to evaluate total mineralization changes in all types of surface waters as this parameter is a good indicator of changes in the water chemical composition (Witczak et al. 2013). Hydrochemical mapping was conducted at the end of August 2014 a period characterized by low-flow regime (Fig. 4). Measurements were taken in rivers and streams with continuous flow as well as in non farming ditches and ponds (Fig. 2, Tab. 2). 
Table 1

Characteristics of measurement points along the rivers

\begin{tabular}{|c|c|c|c|c|}
\hline $\begin{array}{l}\text { Number } \\
\text { of point }\end{array}$ & $\begin{array}{c}\text { Geographical } \\
\text { coordinates } \\
(\mathrm{N}, \mathrm{E})^{\mathrm{A}}\end{array}$ & $\begin{array}{c}\text { Name of the river, } \\
\text { watercourse }^{\mathrm{A}}\end{array}$ & Lenght $[\mathrm{km}]$ & Description of a location \\
\hline I & $\begin{array}{l}51^{\circ} 55^{\prime} 55.3^{\prime \prime} \\
19^{\circ} 28^{\prime} 40.2^{\prime \prime}\end{array}$ & Moszczenica & $30+500$ & a bridge in Michałów \\
\hline II & $\begin{array}{l}51^{\circ} 58^{\prime} 08.1^{\prime \prime} \\
19^{\circ} 26^{\prime} 35.4^{\prime \prime}\end{array}$ & Moszczenica & $23+400$ & before mouth the Czerniawka River in Kotowice \\
\hline III & $\begin{array}{l}51^{\circ} 58^{\prime} 13.1^{\prime \prime} \\
19^{\circ} 26^{\prime} 34.1^{\prime \prime}\end{array}$ & Moszczenica & $23+300$ & after mouth the Czerniawka River in Kotowice \\
\hline IV & $\begin{array}{l}51^{\circ} 58^{\prime} 42.4^{\prime \prime} \\
19^{\circ} 26^{\prime} 29.7^{\prime \prime}\end{array}$ & Moszczenica & $22+200$ & a meander in Kotowice \\
\hline $\mathrm{V}$ & $\begin{array}{l}51^{\circ} 59^{\prime} 49.0^{\prime \prime} \\
19^{\circ} 26^{\prime} 35.2^{\prime \prime}\end{array}$ & Moszczenica & $19+500^{\mathrm{B}}$ & a stream gauge in Gieczno \\
\hline VI & $\begin{array}{l}52^{\circ} 00^{\prime} 34.2^{\prime \prime} \\
19^{\circ} 26^{\prime} 27.4^{\prime \prime}\end{array}$ & Moszczenica & $17+700$ & a bridge in Borowiec \\
\hline VII & $\begin{array}{l}52^{\circ} 01^{\prime} 15.5^{\prime \prime} \\
19^{\circ} 26^{\prime} 42.4^{\prime \prime}\end{array}$ & Moszczenica & $15+900$ & a bridge on the dirt road in Sypin \\
\hline VIII & $\begin{array}{l}51^{\circ} 55^{\prime} 54.2^{\prime \prime} \\
19^{\circ} 28^{\prime} 25.8^{\prime \prime}\end{array}$ & nameless watercourse & $0+400$ & a culvert under the road in Wola Branicka \\
\hline IX & $\begin{array}{l}51^{\circ} 57^{\prime} 11.2^{\prime \prime} \\
19^{\circ} 26^{\prime} 33.2^{\prime \prime}\end{array}$ & Czerniawka & $1+800$ & a bridge on the voivodeship road 708 in Bądków \\
\hline $\mathrm{X}$ & $\begin{array}{l}51^{\circ} 58^{\prime} 07.1^{\prime \prime} \\
19^{\circ} 26^{\prime} 33.3^{\prime \prime}\end{array}$ & Czerniawka & $0+100$ & $\begin{array}{l}\text { before mouth into the Moszczenica } \\
\text { River in Kotowice }\end{array}$ \\
\hline $\mathrm{XI}$ & $\begin{array}{l}51^{\circ} 57^{\prime} 15.5^{\prime \prime} \\
19^{\circ} 26^{\prime} 21.1^{\prime \prime}\end{array}$ & nameless watercourse & $0+400$ & a culvert under the voivodeship road 708 in Bądków \\
\hline XII & $\begin{array}{l}51^{\circ} 57^{\prime} 35.5^{\prime \prime} \\
19^{\circ} 26^{\prime} 20.8^{\prime \prime}\end{array}$ & creek with Jasionka & $0+200$ & a bridge on the dirt road in Kotowice \\
\hline XIII & $\begin{array}{l}51^{\circ} 58^{\prime} 31.9^{\prime \prime} \\
19^{\circ} 26^{\prime} 44.4^{\prime \prime}\end{array}$ & oxbow Moszczenica & $0+400$ & a bridge on the road in Kotowice \\
\hline XIV & $\begin{array}{l}52^{\circ} 00^{\prime} 32.8^{\prime \prime} \\
19^{\circ} 26^{\prime} 07.1^{\prime \prime} \\
\end{array}$ & Dezerta & $4+100$ & a bridge on the dirt road in Borowiec \\
\hline
\end{tabular}

Explanations: number of point according to Figure 2; ${ }^{\text {A }}$ - based on Czarnecka 2005; ${ }^{\text {B }}$ - lenght for the stream gauge in Gieczno (based on Szczepański 1995-1996).

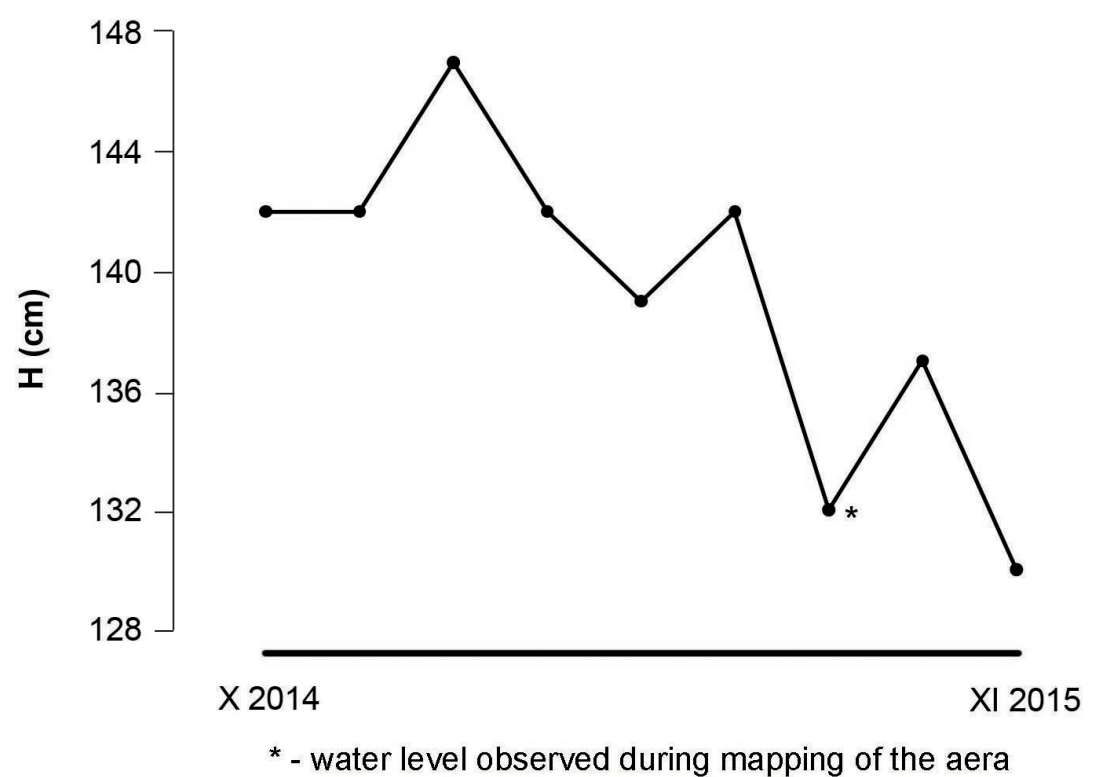

Fig. 4. Water level (H) in the Moszczenica River in Gieczno during period October 2014 -November 2015 


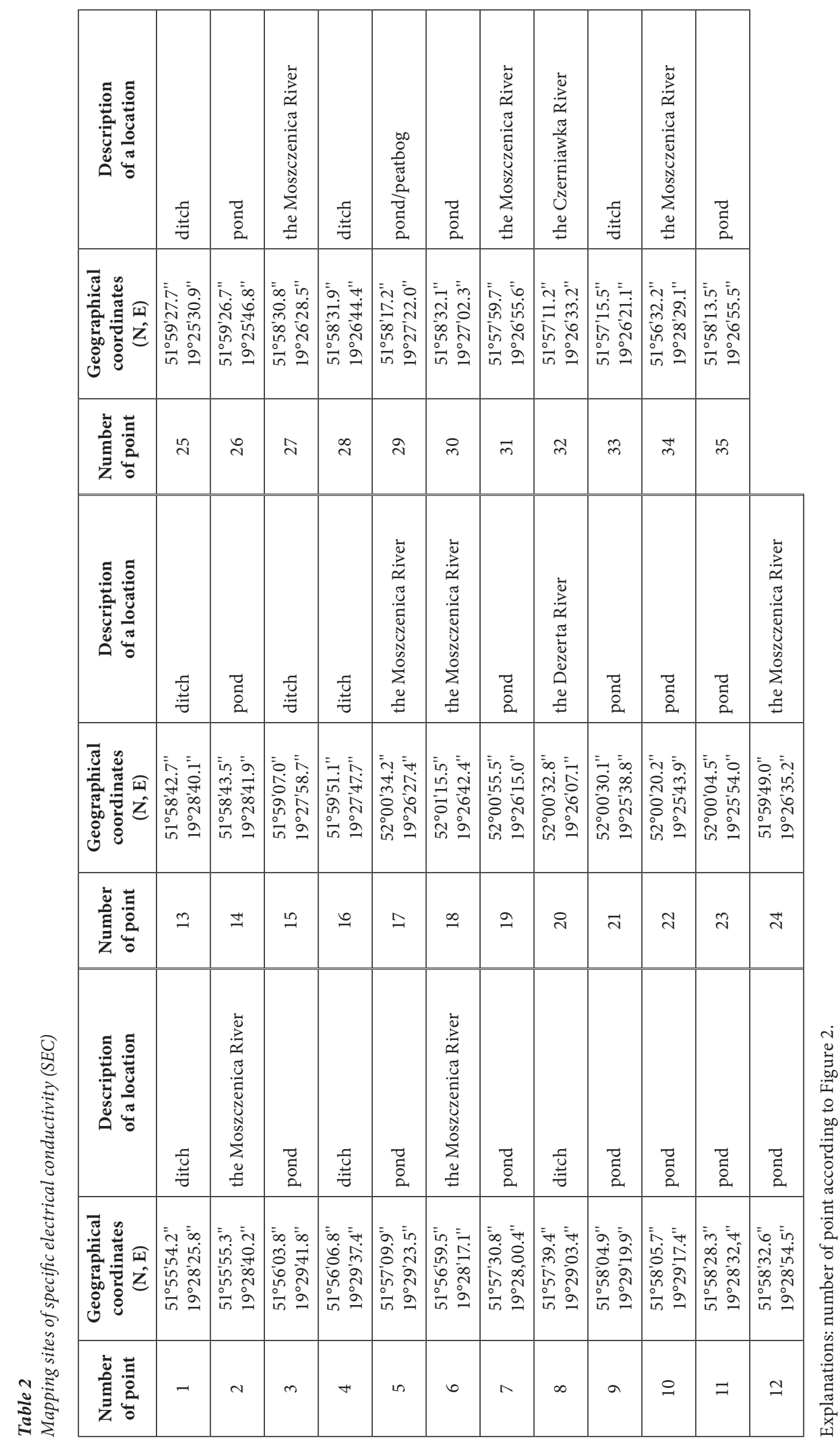




\section{METHODOLOGY \\ OF FIELD RESEARCH ON GROUNDWATER}

The initial analysis of hydrogeochemical conditions in the dome area was conducted on the basis of data coming from 65 hydrogeological observation points (piezometers and wells). The main source of information was the HYDRO Bank data base of the Polish Hydrogeological Survey and the archives of Department of Geology and Geological Concession of the Marshal Office of Łódzkie Voivodeship. Collected hydrochemical data came from the following formation: Quaternary (45 cases), Tertiary (11), Upper Jurassic (6) and Permian residue (3). A relationship between the $\mathrm{Cl}^{-}$concentration and water total mineralization in water from Tertiary and Upper Jurassic formations with the $R^{2}$ value close to unity was observed.

Based on archive data, the chloride baseline of water from Quaternary formation for Rogóźno salt dome was established $(n=45)$. The boundary for the baseline was the concentration of $\mathrm{Cl}^{-}$corresponding to the difference between one standard deviation and estimated parameter median value (68\% of observation) (Zdechlik \& Kania 2003). The lower limit of chloride baseline is $7 \mathrm{mg} \cdot \mathrm{dm}^{-3}$, whereas the higher $90 \mathrm{mg} \cdot \mathrm{dm}^{-3}$.

Some of the wells accumulating water from the Quaternary formation display an anomalous concentration of chloride ions (Fig. 5). Several- or dozen times higher concentration of $\mathrm{Cl}^{-}$in comparison with the higher limit may indicate the presence of migration of saline water into the near-surface area.

In order to establish the scale of salinity of groundwater and its origin, the hydrogeological documentation and marked zones of upward flow of mineralized waters into surface (Fig. 3) was used. A group of hydrogeological formations was selected for the research. The respective criteria were taken into consideration while choosing suitable wells:

- whether accumulated waters indicate higher value of total mineralization or chlorides,

- the close or nearby location of hypothetical zones of saline waters (Fig. 3),

- technical condition enabling the possibility of sampling.

According to the criteria above, six wells and two piezometers were selected (Fig. 2, Tab. 3). One pond was also included as, according to archival data, it was close to the possible upward flow area of the saline waters, strictly connected to a nearby drilling hole. Well and pond sampling included measurements of water temperature (T), $\mathrm{pH}, \mathrm{SEC}$ and reduction-oxidation potential (Eh). An overflow chamber was used in the measurement to protect the water from contact with air.

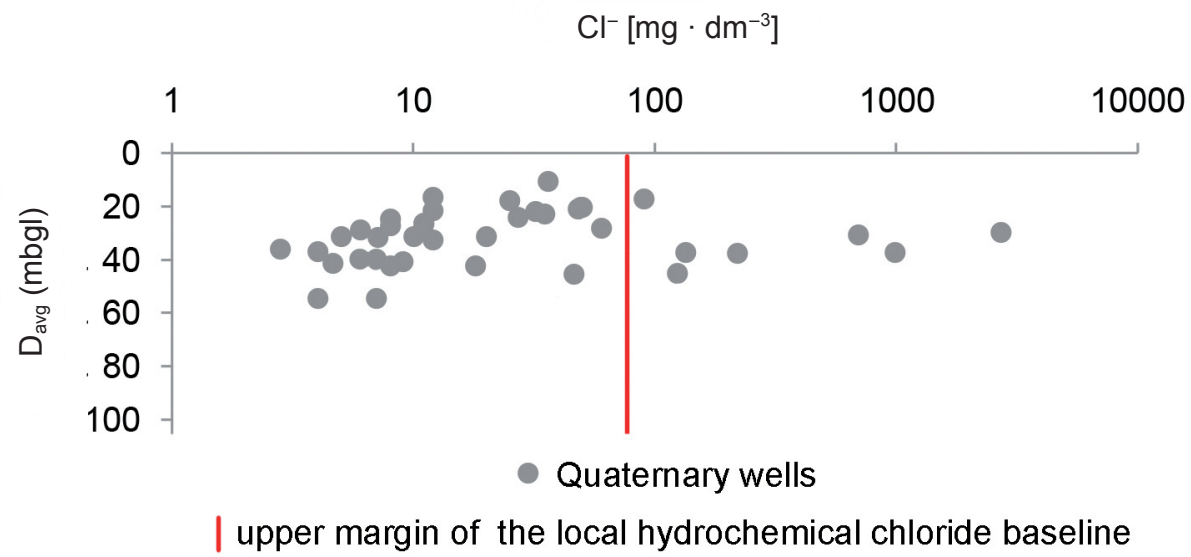

Fig. 5. Change in concentration of chloride ion $\left(\mathrm{Cl}^{-}\right)$in groundwater from Quaternary formation $(D)$ in the area of Rogóźno salt dome with respect to the upper margin of the local hydrochemical chloride baseline 


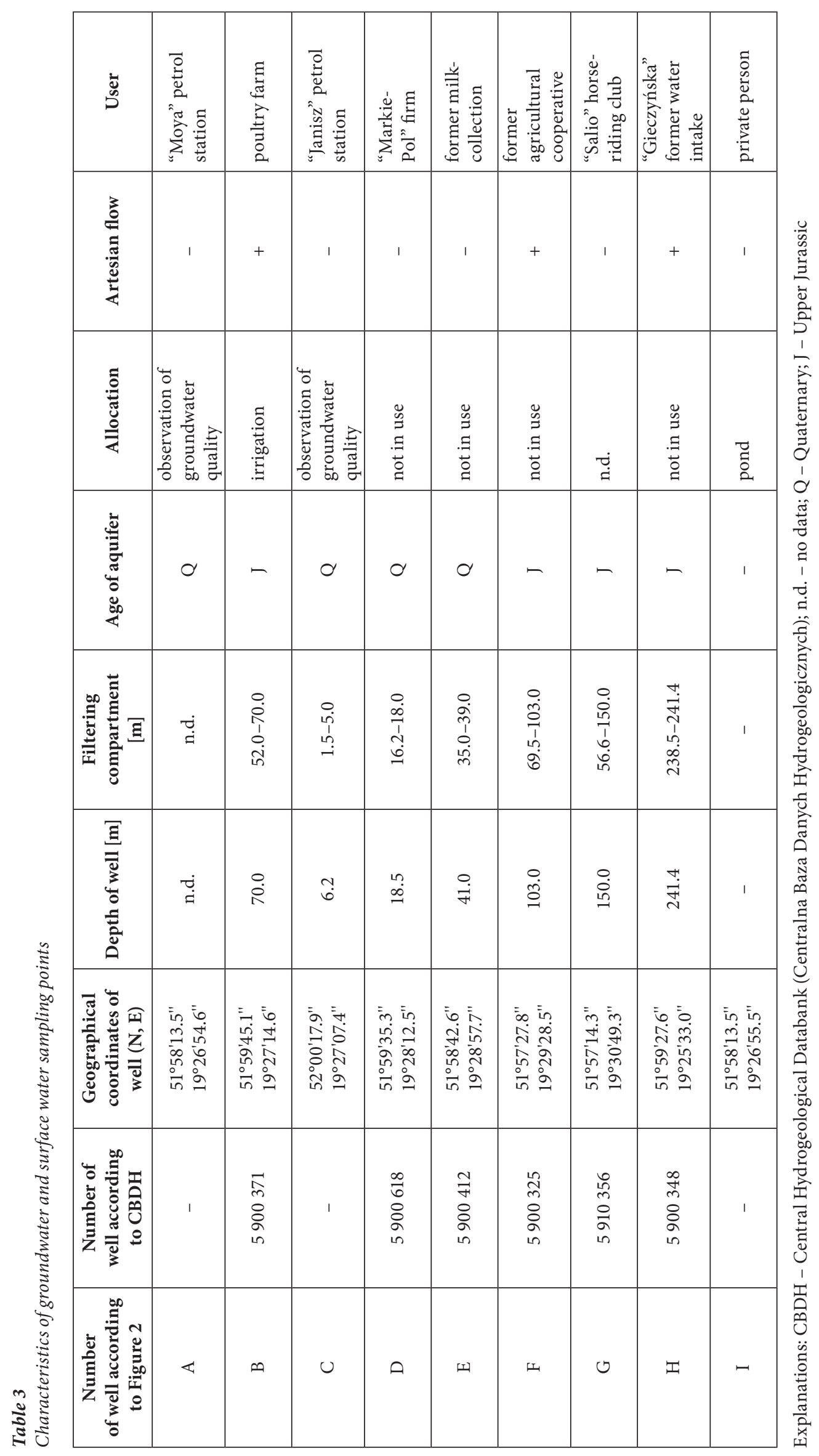




\section{METHODOLOGY OF LABORATORY RESEARCH}

Apart from the measurement of physicochemical parameters in situ, samples of water for laboratory analysis were taken in order to evaluate the presence of the following ions:

- in the case of water sampled from river: $\mathrm{Cl}^{-}$and $\mathrm{Na}^{+}$;

- in the case of groundwater and the pond: anions $\left(\mathrm{Cl}^{-}, \mathrm{HCO}_{3}^{-}, \mathrm{NO}_{3}^{-}, \mathrm{NO}_{2}^{-}, \mathrm{SO}_{4}^{2-}, \mathrm{PO}_{4}^{3-}\right)$, cations $\left(\mathrm{Na}^{+}, \mathrm{K}^{+}, \mathrm{NH}_{4}^{+}, \mathrm{Ca}^{2+}, \mathrm{Mg}^{2+}, \mathrm{Mn}^{2+}, \mathrm{Fe}^{2+}\right)$, and a total amount of dissolved substances of total carbonate and non-carbonate hardness.

Six hydrochemical ratio indexes were used to interpret the chemical composition of groundwater: [1] sodium vs. chloride, [2] sodium vs. sodium and chloride, [3] calcium vs. magnesium, [4] bicarbonate vs. chloride, [5] ESP (Exchange Sodium Percentage), and [6] SAR (Sodium Adsorption Ratio) (e.g. Macioszczyk 1987, Hounslow 1995, Razowska 1999). Their calculation was based on the content of ions in the equivalent form.

- [1] Sodium vs. chloride index: $\frac{\mathrm{Na}^{+}}{\mathrm{Cl}^{-}}$establishes the level of water metamorphosis and its isolation from the area, as well as from other aquifers. With the lowering of the index, water becomes older and the levels of metamorphosis and isolation become higher (Macioszczyk 1987, Pazdro \& Kozerski 1990).

- [2] Sodium vs. sodium and chloride index: $\frac{\mathrm{Na}^{+}}{\mathrm{Na}^{+}+\mathrm{Cl}^{-}}$along with water total mineralization helps determining the sources of sodium in water (Hounslow 1995).

- [3] Calcium vs. magnesium index: $\frac{\mathrm{Ca}^{2+}}{\mathrm{Mg}^{2+}}$ helps in establishing if low-mineralized groundwater are contaminated by calcium or magnesium fertilizers (Macioszczyk 1987).

- [4] Bicarbonate vs. chloride index: $\frac{\mathrm{HCO}_{3}^{-}}{\mathrm{Cl}^{-}}$assess length of the flow of water from the recharge area. A low value of the index means water staying in the rock formation for a longer time (Winid \& Lewkiewicz-Małysa 2005).

- [5] Exchange Sodium Percentage: $\mathrm{ESP}=\frac{\left(\mathrm{Na}^{+}+\mathrm{K}^{+}\right) \cdot 100}{\mathrm{Ca}^{2+}+\mathrm{Mg}^{2+}+\mathrm{Na}^{+}+\mathrm{K}^{+}}[\%]$ establishes the usefulness of water for irrigation purposes. Water with high ESP index may contain colloids and suspensions which have a negative effect on soil permeability (Singh et al. 2014).
- [6] Sodium Adsorption Ratio: $\mathrm{SAR}=\frac{\mathrm{Na}^{+}}{\sqrt{\left(\mathrm{Ca}^{2+}+\mathrm{Mg}^{2+}\right) / 2}}$ expresses relative activity of sodium in exchange reactions with the water impact on soil. The higher the index, the easier it is for $\mathrm{Na}^{+}$to transfer to a sorption complex. At the same time, the probability of high soil salinity increases. The parameter the alkalinity of water as well (Kwaterkiewicz \& Sadurski 1986, Ochman et al. 2011, Singh et al. 2014).

It was assumed that if the areas of higher water total mineralization and higher concentration of chloride ions overlap with areas where the upward flow of water from deeper levels, the salt dome influences water chemistry in the Moszczenica valley. The interpretation of the ion composition of groundwater on the basis of hydrochemical indexes allowed the origin of salinity to be determined.

\section{RESULTS}

Local hydrological conditions during field studies refer to Moszczenica River level on the water gauge in Gieczno in the range of 130-147 cm (Fig. 4) which, according to Szczepański 1995, is a low level. These numbers correspond to the river flow from $0.62 \mathrm{~m}^{3} \cdot \mathrm{s}^{-1}$ to $1.06 \mathrm{~m}^{3} \cdot \mathrm{s}^{-1}$ (according to the Institute of Meteorology and Water Management); which represent average level in this part of the river (Szczepański 1995).

The minimum and maximum values of examined physico-chemical parameters observed on measure-control gauges are represented in Table 4 . There is a continuous pattern in examined physico-chemical parameters of water in the middle course of the Moszczenica River. Prior to connection with the tributary Czerniawka River, the average statistical water chemistry data and their range were relatively high. After the waters are combined, the parameters are lower and the range between them is reduced, then increased again in the lower part of the Moszczenica River (Fig. 6A-C).

The analyzed SEC area in surface waters undergoes important changes (Fig. 7). The area of lower than $400 \mu \mathrm{S} \cdot \mathrm{cm}^{-1}$ is located along Moszczenica River channel and the upper part of Czerniawka River. SEC of surface waters increases with a growing distance from the Moszczenica River. 

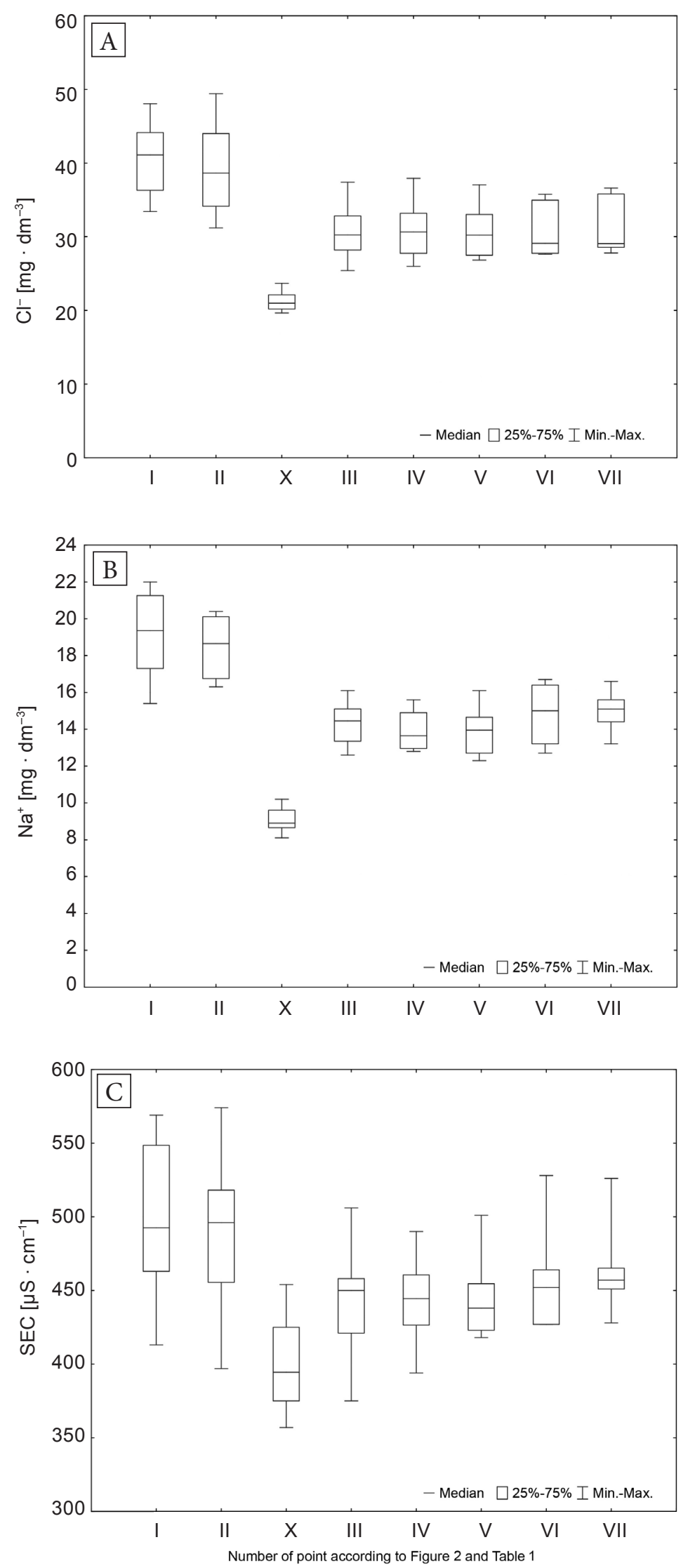

Fig. 6. Statistical distribution of chloride ion $\left(\mathrm{Cl}^{-}\right)$in measure-control points in the Moszczenica and the Czerniawka rivers (A); statistical distribution of sodium ion $\left(\mathrm{Na}^{+}\right)$in measure-control points in the Moszczenica and the Czerniawka rivers (B); statistical distribution of specific electrical conductivity (SEC) in measure-control points in the Moszczenica and the Czerniawka rivers (C) 


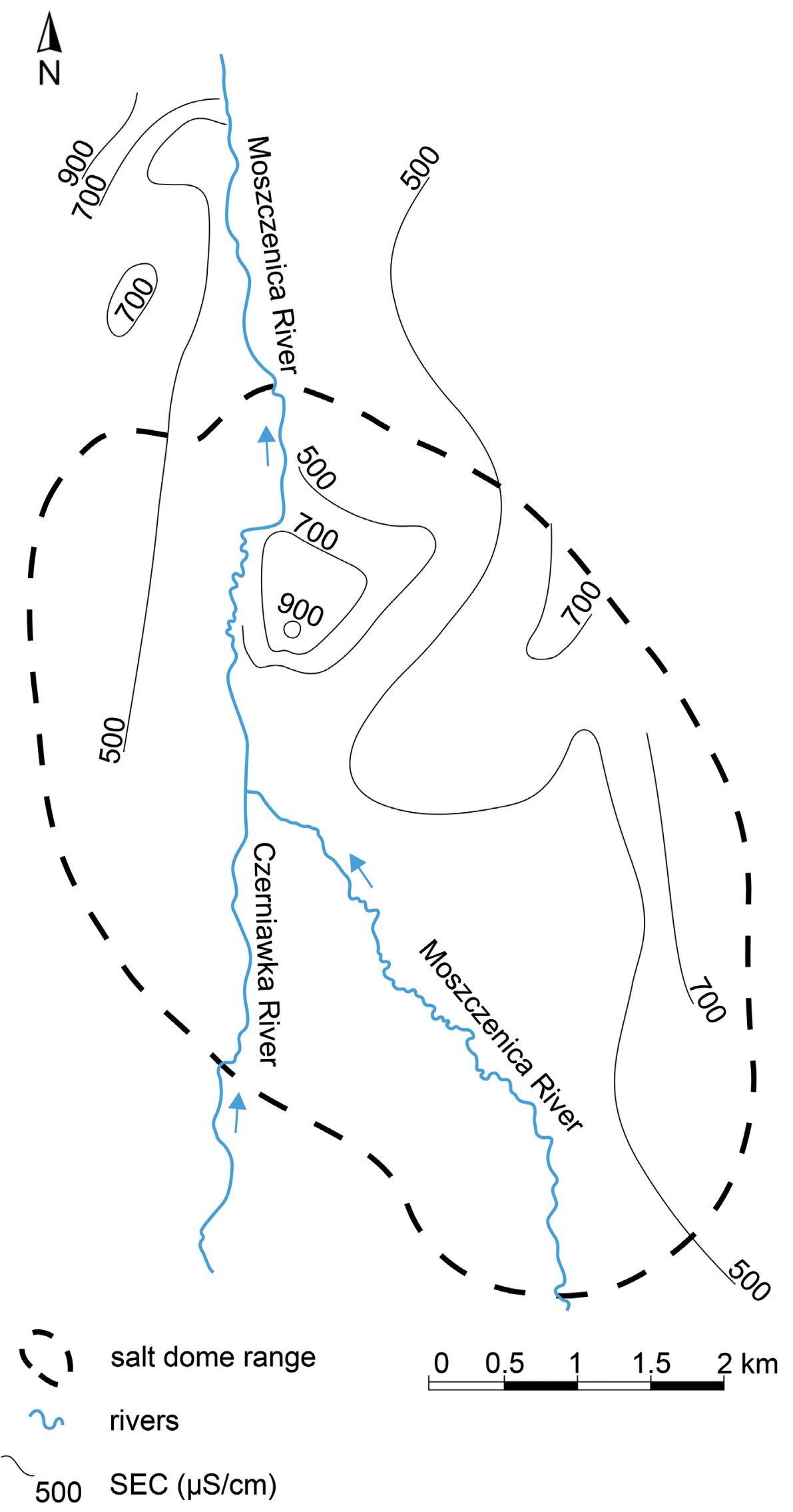

Fig. 7. Changes in conductivity (SEC) of surface water in the Rogóźno region 
Table 4

Minimum and maximum values of selected hydrochemical elements of examined rivers in selected measure-control points

\begin{tabular}{|c|c|c|c|c|c|c|c|c|}
\hline \multirow{2}{*}{ Objects $(n)$} & \multicolumn{2}{|c|}{$\mathrm{pH}$} & \multicolumn{2}{|c|}{$\mathrm{SEC}\left[\mu \mathrm{S} \cdot \mathrm{cm}^{-1}\right]$} & \multicolumn{2}{|c|}{$\mathrm{Cl}^{-}\left[\mathrm{mg} \cdot \mathrm{dm}^{-3}\right]$} & \multicolumn{2}{|c|}{$\mathrm{Na}^{+}\left[\mathrm{mg} \cdot \mathrm{dm}^{-3}\right]$} \\
\hline & $\min$ & $\max$ & $\min$ & $\max$ & $\min$ & $\max$ & $\min$ & $\max$ \\
\hline All objects (14) & 4.77 & 8.75 & 317 & 639 & 14.0 & 49.4 & 4.9 & 27.4 \\
\hline Points on the Moszczenica River (7) & 7.11 & 8.75 & 375 & 579 & 25.4 & 49.4 & 12.3 & 22.0 \\
\hline $\begin{array}{l}\text { Points on the tributaries of the } \\
\text { Moszczenica River ( } 7 \text { ) }\end{array}$ & 4.77 & 8.54 & 317 & 639 & 14.0 & 45.5 & 4.9 & 27.4 \\
\hline
\end{tabular}

The highest value of the parameter SEC $\left(913 \mu \mathrm{S} \cdot \mathrm{cm}^{-1}\right)$ was observed in the pond located in Rogóźno. High conductivity contributes to the identification of an anomaly area around the pond, within larger area of relatively consistent spatial variability of SEC. Gradual increase of SEC is observed in the direction of the Warsaw-Berlin glacial valley, on the western side of the Moszczenica River.

Hydrogeochemical characteristics of sampled objects are presented in Kurlov formula (Tab. 5); supplemented with information on water $\mathrm{pH}$.

\section{Table 5}

Chemical analysis of sampled objects on the basis of Kurlov formula

\begin{tabular}{|c|c|}
\hline Number of well & Kurlov formula \\
\hline A & $\mathrm{M}^{0.3} \frac{\mathrm{HCO}_{3}^{38} \mathrm{Cl}^{30} \mathrm{SO}_{4}^{24} \mathrm{NO}_{3}^{7}}{\mathrm{Ca}^{62} \mathrm{Na}^{22} \mathrm{Mg}^{10} \mathrm{~K}^{6}} \mathrm{~T}^{13}, \mathrm{pH}^{6.16}$ \\
\hline B & $\mathrm{M}^{2.1} \frac{\mathrm{Cl}^{83} \mathrm{HCO}_{3}^{9} \mathrm{SO}_{4}^{7}}{\mathrm{Na}^{87} \mathrm{Ca}^{8} \mathrm{Mg}^{4} \mathrm{~K}^{1}} \mathrm{~T}^{9}, \mathrm{pH}^{7.54}$ \\
\hline $\mathrm{C}$ & $\mathrm{M}^{0.5} \frac{\mathrm{NO}_{3}^{50} \mathrm{SO}_{4}^{26} \mathrm{Cl}^{15} \mathrm{HCO}_{3}^{9}}{\mathrm{Ca}^{63} \mathrm{Mg}^{17} \mathrm{Na}^{15} \mathrm{~K}^{5}} \mathrm{~T}^{14}, \mathrm{pH}^{5.73}$ \\
\hline $\mathrm{D}$ & $\mathrm{M}^{0.4} \frac{\mathrm{HCO}_{3}^{56} \mathrm{Cl}^{37} \mathrm{SO}_{4}^{5} \mathrm{NO}_{3}^{2}}{\mathrm{Ca}^{54} \mathrm{Na}^{35} \mathrm{Mg}^{6} \mathrm{~K}^{3} \mathrm{NH}_{4}^{2}} \mathrm{~T}^{11}, \mathrm{pH}^{7.24}$ \\
\hline $\mathrm{E}$ & $\mathrm{M}^{0.6} \frac{\mathrm{HCO}_{3}^{50} \mathrm{Cl}^{44} \mathrm{SO}_{4}^{5}}{\mathrm{Ca}^{47} \mathrm{Na}^{43} \mathrm{Mg}^{9} \mathrm{~K}^{1}} \mathrm{~T}^{10}, \mathrm{pH}^{7.33}$ \\
\hline $\mathrm{F}$ & $\mathrm{M}^{0.4} \frac{\mathrm{HCO}_{3}^{68} \mathrm{Cl}^{26} \mathrm{SO}_{4}^{5}}{\mathrm{Ca}^{63} \mathrm{Na}^{24} \mathrm{Mg}^{12} \mathrm{~K}^{1}} \mathrm{~T}^{24}, \mathrm{pH}^{10.7}$ \\
\hline G & $\mathrm{M}^{0.3} \frac{\mathrm{HCO}_{3}^{87} \mathrm{SO}_{4}^{7} \mathrm{Cl}^{5} \mathrm{NO}_{3}^{1}}{\mathrm{Ca}^{73} \mathrm{Mg}^{13} \mathrm{Na}^{13} \mathrm{~K}^{1}} \mathrm{~T}^{10}, \mathrm{pH}^{9.39}$ \\
\hline $\mathrm{H}$ & $\mathrm{M}^{1.0} \frac{\mathrm{Cl}^{86} \mathrm{HCO}_{3}^{9} \mathrm{SO}_{4}^{5}}{\mathrm{Na}^{67} \mathrm{Ca}^{26} \mathrm{Mg}^{6} \mathrm{~K}^{1}} \mathrm{~T}^{24}, \mathrm{pH}^{7.84}$ \\
\hline I & $\mathrm{M}^{0.8} \frac{\mathrm{Cl}^{47} \mathrm{HCO}_{3}^{37} \mathrm{SO}_{4}^{16}}{\mathrm{Ca}^{53} \mathrm{Na}^{34} \mathrm{Mg}^{9} \mathrm{~K}^{4}} \mathrm{~T}^{1}, \mathrm{pH}^{5.71}$ \\
\hline
\end{tabular}

Explanations: number of well according to Figure 2 and Table 3. 
Groundwater, with semi-acid $\mathrm{pH}$, flows into the shallowest piezometers. The ionic composition of these waters indicates their relative similarity. The important difference is shown with respect to a dominant anion. Bicarbonates are dominant in water sampled from piezometer $(\mathrm{A})$ whereas nitrates are dominant in water flowing into the piezometer (C).

Quaternary deep wells (D, E) are recharged with waters that do not have total mineralization higher than $600 \mathrm{mg} \cdot \mathrm{dm}^{-3}$; they consist mainly of bicarbonates, chlorides, calcium and sodium. Other ions are present, but in small concentrations and the temperature and $\mathrm{pH}$ of these waters are similar.

Wells collecting water from Upper Jurassic formations can be divided into two groups. Each of these groups is characterized by unique physico-chemical parameters. The first group consists of wells $(G)$ and $(F)$. Water flowing into them is alkaline and of low total mineralization. Water in the well $(\mathrm{F})$ is bicarbonate-calcium dominated by significant concentrations of $\mathrm{Cl}^{-}$and $\mathrm{Na}^{+}$. This well has an artesian flow of about $1.7 \mathrm{dm}^{3} \cdot \mathrm{s}^{-1}$ and temperature of $24.0^{\circ} \mathrm{C}$. The second group consists of wells (B) and (H). In each of the wells, the groundwater table is stabilized above the surface. In (B) the artesian uplift reaches $0.18 \mathrm{~m}$, whereas in $(\mathrm{H})$ it is about $4.8 \mathrm{~m}$ with the simultaneous outflow of water with temperature of $24.0^{\circ} \mathrm{C}$. Mineral chloride-sodium waters flow into the well; wherein higher rate of calcium is present in the well (H). The chemical analysis indicates that in the pond (I) there is a slightly acidic acratopegae and its main components are: $\mathrm{Cl}^{-}, \mathrm{HCO}_{3}^{-}, \mathrm{Na}^{+}$and $\mathrm{Ca}^{2+}$.

\section{DISCUSSION}

Increased flow volumes of the Moszczenica River correlated with decreased $\mathrm{pH}\left(R^{2}=0.7\right.$; Fig. 8A) and an increased concentration of $\mathrm{Na}^{+}\left(R^{2}=0.6\right.$; Fig. $8 \mathrm{~B})$. There is no observable statistically significant correlation between flow volume and SEC and $\mathrm{Cl}^{-}$concentration, which could be caused by diverse sources of $\mathrm{Cl}^{-}$(Mazurek 2000). During high flows, some of the smallest and biggest rates of SEC and $\mathrm{Cl}^{-}$were observed. The correlation between conductivity and $\mathrm{Cl}^{-}$ion in water is observed only when concentration of $\mathrm{Cl}^{-}$is very high. Correlation between concentrations of $\mathrm{Na}^{+}$ and $\mathrm{Cl}^{-}$is good, particularly at high concentrations. In the central and northern stretch of the Moszczenica River, which is within the salt dome area and outside its northern border, there was no significant increase of measured physicochemical parameters (Fig. 6A-C) while significantly higher salinity was observed in its tributary, the Dezerta River. The Moszczenica River, in contrast to other rivers in the region, is characterized with average SEC and concentration of $\mathrm{Cl}^{-}$ion, which suggests relatively the limited influence of the anthropogenic impact on the water chemistry (Ocena stanu wód powierzchniowych, 2013).

SEC overall increases with a increasing distance from the Moszczenica River and the Czerniawka River respectively (Fig. 7). This spatial regularity is disturbed by certain 'anomalous' zones. Elevated SEC anomalies around towns of Władysławów and Lorenki overlap with areas of possible ascent of water from Tertiary formation (Fig. 3) (Górecki 2015). The results obtained from the hydrochemical analyses may suggest the presence of certain zones where saline groundwater coming from the area around the dome are flowing up to the surface.

Six ionic ratios have been calculated based on measured parameters and used to interpret processes influencing water chemistry in specific observation points (Tab. 6). The location of the piezometers (A), (C) next to gas stations, residential areas or farmlands influences groundwater chemistry. Water sampled from the well (A) showed $\mathrm{Cl}^{-}$concentration of over $42 \mathrm{mg} \cdot \mathrm{dm}^{-3}$ (Tab. 5). In comparison with the archive data coming from piezometers, the concentration is higher but it is within the range of the hydrochemical baseline which does not point to any anomalous rates of ions in water. The ratio between potassium and sodium is low values and may be an evidence of an anomaly in the aquifer. Other evidence of the anthropogenic impact are the elevated concentrations of $\mathrm{SO}_{4}{ }^{2-}, \mathrm{PO}_{4}^{3-}$ and $\mathrm{NO}_{3}{ }^{-}$. The low $\mathrm{pH}$ of water is connected to the presence of sulfates in the quantity bigger than $20 \%$ mval. Permanent anthropogenic contamination of water is proven by the presence of all mineral forms of nitrogen $\left(\mathrm{NH}_{4}^{+}, \mathrm{NO}_{2}^{-}, \mathrm{NO}_{3}^{-}\right)$, increased content of nitrogen, phosphates and sulfates (Macioszczyk \& 
Dobrzyński 2002) and cause low values of ionic ratio $\mathrm{Na} / \mathrm{Cl}$ (index 1 ), which falsely suggest the presence of a very good and long-lasting isolation from the surface which classifies groundwater as relict, highly metamorphosed. High values of ionic ratio $\mathrm{HCO}_{3} / \mathrm{Cl}$ (index 4) in contrast, represent waters in the active recharge zone. Contamination of groundwater might be indicated by ionic ratio $\mathrm{HCO}_{3} / \mathrm{Cl}$. Water sampled from the well (C) contains $176 \mathrm{mg} \cdot \mathrm{dm}^{-3}$ of $\mathrm{NO}_{3}^{-}$ion, which strongly suggests water contamination. This is also confirmed in the low value of the $\mathrm{HCO}_{3} / \mathrm{Cl}$ ratio, which is shown in a low content of bicarbonates (Tab. 5). The low $\mathrm{pH}$ of water may be linked to the anomalous content of $\mathrm{NO}_{3}^{-}$(Pazdro \& Kozerski 1990) while the lack of an impermeable layer and the shallow presence of groundwater contributes to the high level of oxidation-reduction potential $(\mathrm{Eh}=238 \mathrm{mV})$. However, the environment is transitional, between oxidising and reducing with relatively low $\mathrm{pH}$ in the aquifer (Tab. 5) (Witczak et al. 2013).
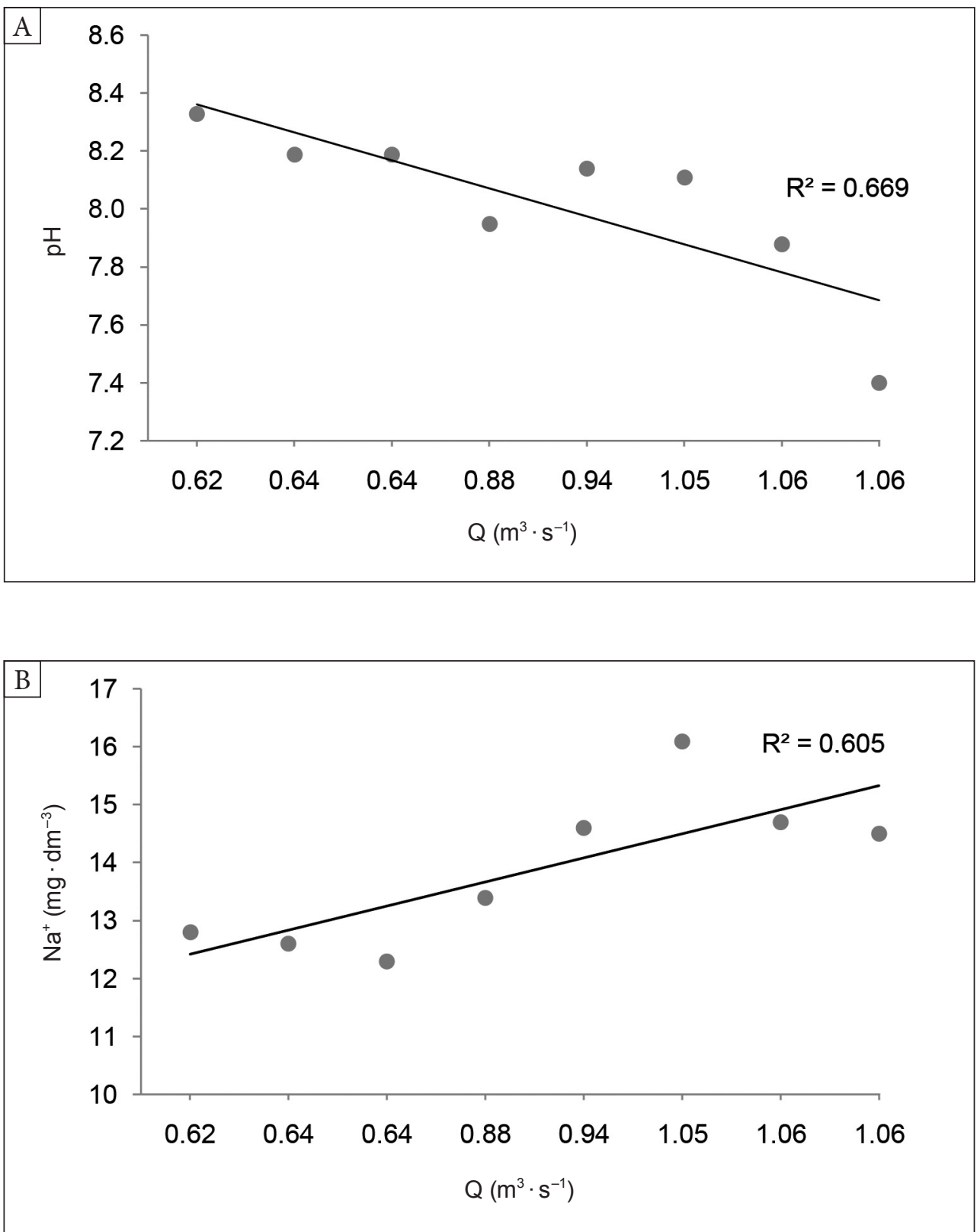

Fig. 8. Correlation between the water flow $(Q)$ and its $p H$ reaction $(p H)$ on Gieczno water gauge $(A)$; correlation between the water flow (Q) and sodium ion content $\left(\mathrm{Na}^{+}\right)$on Gieczno water gauge (B) 
Table 6

Characteristics of groundwater and surface waters on the basis of hydrochemical indicators

\begin{tabular}{|c|c|c|c|c|c|c|c|c|c|c|}
\hline \multirow{2}{*}{ Indicator } & \multirow{2}{*}{ Interpretation } & \multicolumn{9}{|c|}{ Number of object } \\
\hline & & $\mathbf{A}$ & B & $\mathrm{C}$ & D & $\mathbf{E}$ & $\mathbf{F}$ & G & $\mathbf{H}$ & I \\
\hline \multirow{3}{*}{$\frac{\mathrm{Na}^{+}}{\mathrm{Cl}^{-}}$} & very good insulation & $\mathrm{X}$ & & & $\mathrm{X}$ & & $\mathrm{X}$ & & $\mathrm{X}$ & $\mathrm{X}$ \\
\hline & good insulation & & $\mathrm{X}$ & $\mathrm{X}$ & & $\mathrm{X}$ & & & & \\
\hline & no insulation & & & & & & & $\mathrm{X}$ & & \\
\hline \multirow{4}{*}{$\frac{\mathrm{Na}^{+}}{\mathrm{Na}^{+}+\mathrm{Cl}^{-}}$} & halite solution & & $\mathrm{X}^{1}$ & & & & & & & \\
\hline & sodium source other than halite & & & & & & & $\mathrm{X}$ & & \\
\hline & brine & & $\mathrm{X}^{1}$ & $\mathrm{X}$ & & $\mathrm{X}$ & & & $\mathrm{X}$ & $\mathrm{X}$ \\
\hline & anthropopressure & $\mathrm{X}$ & & & $\mathrm{X}$ & & $\mathrm{X}$ & & & \\
\hline \multirow{2}{*}{$\frac{\mathrm{Ca}^{2+}}{\mathrm{Mg}^{2+}}$} & contamination & $\mathrm{X}$ & $\mathrm{X}$ & & $\mathrm{X}$ & & & & & \\
\hline & no contamination & & & $\mathrm{X}$ & & $\mathrm{X}$ & $\mathrm{X}$ & $\mathrm{X}$ & $\mathrm{X}$ & $\mathrm{X}$ \\
\hline \multirow{3}{*}{$\frac{\mathrm{HCO}_{3}^{-}}{\mathrm{Cl}^{-}}$} & minimal recharge & & $\mathrm{X}$ & & & & & & $\mathrm{X}$ & \\
\hline & transistion zone & & & $\mathrm{X}$ & & & & & & $\mathrm{X}$ \\
\hline & active recharge & $\mathrm{X}$ & & & $\mathrm{X}$ & $\mathrm{X}$ & $\mathrm{X}$ & $\mathrm{X}$ & & \\
\hline \multirow{2}{*}{ ESP } & suitable for irrigation & $\mathrm{X}$ & & $\mathrm{X}$ & $\mathrm{X}$ & $\mathrm{X}$ & $\mathrm{X}$ & $\mathrm{X}$ & & $\mathrm{X}$ \\
\hline & unsuitable for irrigation & & $\mathrm{X}$ & & & & & & $\mathrm{X}$ & \\
\hline \multirow{2}{*}{ SAR } & risk of soil salinity & & $\mathrm{X}$ & & & $\mathrm{X}$ & & & $\mathrm{X}$ & \\
\hline & no risk of soil salinity & $\mathrm{X}$ & & $\mathrm{X}$ & $\mathrm{X}$ & & $\mathrm{X}$ & $\mathrm{X}$ & & $\mathrm{X}$ \\
\hline
\end{tabular}

Explanations: number of object according to Figure 2, Table 3 and Table $5 ;{ }^{1}$ - ratio value allows for classification into two classes.

The high value of ionic ratio $\mathrm{Na} / \mathrm{Cl}$ and low value of ionic ratio $\mathrm{HCO}_{3} / \mathrm{Cl}$ indicate waters isolated from the surface; such waters have a difficult contact with surface and infiltration waters. However, groundwater is present approximately $2 \mathrm{~m}$ b.g.l with no isolating aquifer (the archive of the Łódzkie Voivodeship Marshall Office, catalogue number 1094). The low result of $\mathrm{Na} / \mathrm{Na}+\mathrm{Cl}$ ratio (index 2) with increased total mineralization also improperly characterizes this water as saline originating from geogenical salinity. This waters shows signs of contamination.

The deeper and shallow aquifers are hydraulically connected, something which was observed during pumping test in well (D), when flow occurred from one aquifer to another. The shallow aquifer is not isolated from the surface and is vulnerable to contamination. Bicarbonate and calcium ions overall are dominant ions but $\mathrm{Cl}^{-}$and $\mathrm{Na}^{+}$ ions are also present in high concentrations. Concentration of $\mathrm{Cl}^{-}$of $70 \mathrm{mg} \cdot \mathrm{dm}^{-3}$ in groundwater from Quaternary formation in the Rogóźno area is high, but not above the baseline range. Increased concentration of $\mathrm{Cl}^{-}$and $\mathrm{Na}^{+}$indicates that waters flowing into the well may be in contact with waters of high salinity around the salt dome. The ion balance (Tab. 5) and values of hydrochemical indexes (Tab. 6) suggest that water in the well has characteristic features of both waters typical for the active recharge zone and of waters influenced by anthropological and geogenic factors. Interpretation of ionic ratios is difficult because of interference between anthropogenic contamination and geogenic contamination. The chemical composition and ionic ratio ssuggest that water in the well (E) is a combintation of highly mineralized waters mixed with natural groundwater from the active recharge zone. High concentration of $\mathrm{Cl}^{-}$ (136 $\mathrm{mg} \cdot \mathrm{dm}^{-3}$ ), accompanied by high concentrations of $\mathrm{Na}^{+}$(Tab. 5) suggests a geogenically saline water. In contrast to well (D), ion balance of the well water does not indicate that the Quaternary aquifer is in hydraulic contact with the first shallow aquifer, as it was in well (D). The environment in the aquifer is slightly reducing (Witczak et al. 2013). Values of the ionic ratio $\mathrm{Na} / \mathrm{Na}+\mathrm{Cl}$ (index 2) suggest a possible influence of the salt dome on the water chemistry (Tab. 6). The ionic ratio $\mathrm{Na} / \mathrm{Cl}$ (index 1) informs about good isolation of the aquifer from the surface with only limited 
contact with infiltration water. However, along with the presence of $\mathrm{Na}^{+}$, a risk of soil salinity is present (index 5). The ion composition of water sampled from wells (D) and (E), as well as hydrochemical indexes confirm the possibility of upward water flow (geogenically mineralized water) from deeper aquifers indicated in Figure 3 (Górecki 2015).

Well (B) is located right outside the northern border of the salt dome. The chemical analysis indicated that there are two ions dominating in the water: $\mathrm{Cl}^{-}$and $\mathrm{Na}^{+}$(Tab. 5). The high concentration of these ions is characteristic for deep groundwater influenced by the leaching of rock salt or other evaporites (Macioszczyk \& Dobrzyński 2002, Witczak et al. 2013). Indirect contact of water with saline rocks is also indicated by its high total mineralization. The water is slightly alkaline (Tab. 5) and has low value of oxidizing-reducing potential $(\mathrm{Eh}=-518 \mathrm{mV})$. Reducing the environment causes the minor participation of reduced concentrations of $\mathrm{SO}_{4}{ }^{2-}$ which undergoes reductions and enriches water in $\mathrm{H}_{2} \mathrm{~S}$ (Macioszczyk \& Dobrzyński 2002). Despite reducing conditions, the concentration of sulfates in water amounts to $110 \mathrm{mg} \cdot \mathrm{dm}^{-3}$ which, in comparison with other water from the Upper Jurassic aquifer that were analyzed, is high. The dissolution of evaporites rich in this ion may provide a significant amount of sulfates. However, there is no increased concentration of $\mathrm{K}^{+}$or $\mathrm{Mg}^{2+}$ (Pazdro \& Kozerski 1990) which are, frequently, related to the process. The slates confining the deeper aquifer could contribute to higher concentrations of $\mathrm{SO}_{4}^{2-}$. The possibility of the salt dome influencing water chemistry is expressed in low values of ionic ratio $\mathrm{HCO}_{3} / \mathrm{Cl}$ (index 4), characteristic for saline waters (Tab. 6). The ionic ratio $\mathrm{Na} / \mathrm{Na}+\mathrm{Cl}$ (index 2) (about 0.5) informs us that the sodium in water comes from dissolution of halite. The well is currently used occassionally, only in the event of long drought periods to irrigate the surrounding area. A high concentration of $\mathrm{Na}^{+}$in comparison with other cations means the water would be unusable for irrigation (index 5). Any one using such water for irrigation may result in increased soil salinity (index 6). Upper Jurassic aquifers derived through the well (F) are located under a thick sequence of impermeable rocks. The water temperature in the outflow reaches $24.0^{\circ} \mathrm{C}$ (Tab. 5), which is classified as hypothermal waters
(Pazdro \& Kozerski 1990). The conditions in the water are transitional, between oxidizing and reducing with unusually high $\mathrm{pH}$ (10.7). It is a rare occurrence that such an alkaline would be caused by geogenical factors (Witczak et al. 2013). There is no indication of any present contaminations, and possibly such a high $\mathrm{pH}$ is caused by naturally occuring conditions. The hydrochemical type of water and ionic ratios (Tab. 6) may confirm, as in case of the well (B), mixing of saline and natural groundwater. However, the ionic composition suggests that natural groundwater has a significantly higher impact in this mixture. It is indicated in confirmed with relatively low concentration of $\mathrm{Cl}^{-}$and $\mathrm{Na}^{+}$, low water total mineralization and ionic ratios $\mathrm{Na} / \mathrm{Cl}$ and $\mathrm{Na} / \mathrm{Na}+\mathrm{Cl}$, respectively. The ionic ratio $\mathrm{HCO}_{3} / \mathrm{Cl}$ is typical for waters of active recharge zone; it is also indicated by carbonate hardness (Pazdro \& Kozerski 1990). Value of ratios ESP (index 5) and SAR (index 6) enables the water to be used for irrigation with no risk of increased salinity in the aquifer. Well $(G)$ is located outside the eastern border of the salt dome. The low concentration of chlorides and sodium suggests that there is no contact with waters flowing over the salt dome (Tab. 5). Ratios $\mathrm{Na} / \mathrm{Cl}$ and $\mathrm{HCO}_{3} / \mathrm{Cl}$ inform us about the presence of waters in the active recharge zone (Tab. 6). It is also indicated by the carbonate hardness (Pazdro \& Kozerski 1990). Lack of contamination flow is indicated by the ratio $\mathrm{Ca} / \mathrm{Mg}$. There are three dominant ions in the sample $(\mathrm{H}): \mathrm{Cl}^{-}, \mathrm{Na}^{+}$and $\mathrm{Ca}^{2+}$ (Tab. 5). The concentration of the chloride anion amounts to over $408 \mathrm{mg} \cdot \mathrm{dm}^{-3}$, and sodium cation to over $206 \mathrm{mg} \cdot \mathrm{dm}^{-3}$. The increased value of $\mathrm{Ca}^{2+}$ in the saline water may be caused by ion exchange. It occurs when high $\mathrm{NaCl}$ waters are in contact with carbonate rocks. This type of water is frequently present in deep hydrogeological structures (Pazdro \& Kozerski 1990). Water in the outflow has a temperature of $24.0^{\circ} \mathrm{C}$ so, just like in the case of water from the well (F), which is classified as hypothermal waters. The total dissolved solids amounts to more than $1 \mathrm{~g} \cdot \mathrm{dm}^{-3}$, which classifies this water as having a relatively low mineral concentration (Pazdro \& Kozerski 1990) in the poorly reductive environment (Witczak et al. 2013). This water flows from a neglected well through a narrow stream, into a nearby meadow and finally into a ditch. The surrounding area is endangered with the contamination of the soil and 
the shallow aquifer due to improper protection of self-flowing saline waters. The ratio $\mathrm{Na} / \mathrm{Na}+\mathrm{Cl}$ characterizes water as saline water which, according to the ratio $\mathrm{Na} / \mathrm{Cl}$, is very well isolated from the surface area (Tab. 6). The ratio $\mathrm{HCO}_{3} / \mathrm{Cl}$ confirms the good isolation from surface water. The high total mineralization and content of chlorides and sodium causes the water to be unusable for irrigation (index 5). In the Rogóźno area, groundwater from the Upper Jurassic formation contact with a saline structure - a hydraulic barrier that also causes modifications in physico-chemical composition of the flowing water. The influence of salt dome on water from Upper Jurassic aquifer is found in the ion composition of groundwater derived from wells located on opposite sides. Groundwater derived from wells (F) and (G) do not indicate any contact with the salt dome. On the other side of the diapir, there is a high geogenical influence of saline rocks on physico-chemical composition of groundwater in wells $(\mathrm{B})$ and $(\mathrm{H})$.

There are four ions dominating the surface water in the pond (I): $\mathrm{Ca}^{2+}, \mathrm{Na}^{+}, \mathrm{HCO}^{-}$and
$\mathrm{Cl}^{-}$(Tab. 5). High concentrations of $\mathrm{Cl}^{-}$and $\mathrm{Na}^{+}$ suggest the inflow of geogenically saline waters. A minimum presence of mineral forms of nitrogen and phosphorus confirms natural, instead of anthropological salinity (Górski 2001, Macioszczyk \& Dobrzyński 2002, Witczak et al. 2013). Increased concentration of $\mathrm{K}^{+}$and $\mathrm{Mg}^{2+}$ may suggest the inflow of contamination from fertilizers. However, due to lack of any other signs of anthropopression, it is very likely that the source of these ions can be found in leaching of potassium-magnesium salts. Surface water in the pond may mix with saline water, which flows through a nearby unsealed exploration hole. A similar situation in groundwater is observed in wells (D), (E) and (F), respectively. According to archive documentation of the Marshal Office of Łódzkie Voivodeship, there had been a few piezometers near the pond in the past, characterized by very high concentration of chloride and sodium ions. The presence of not properly maintained well $\mathrm{H}-4$ located close to the pond may cause the inflow of saline waters into the surface. A similar situation occurs in the outflow $(\mathrm{H})$.

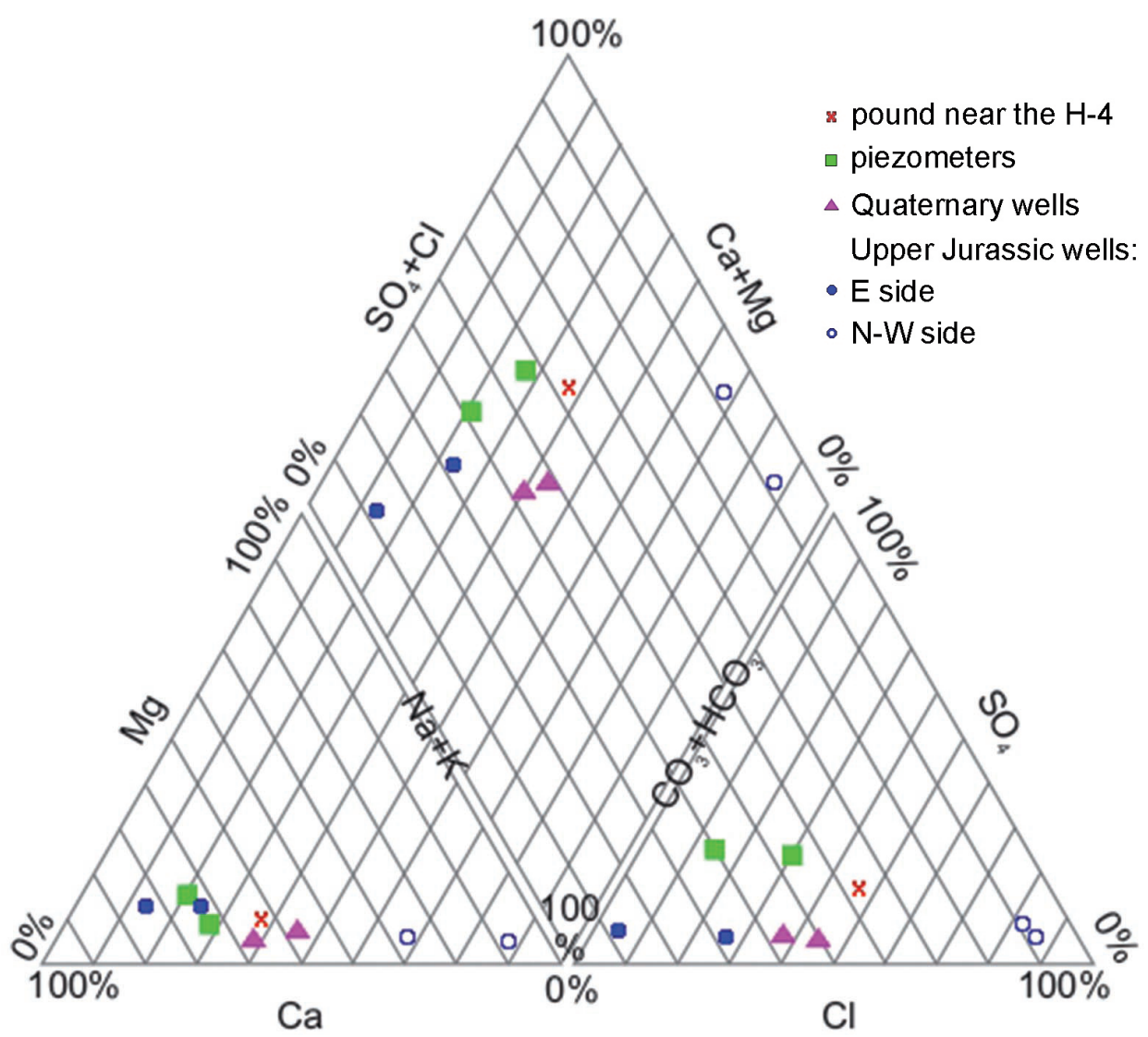

Fig. 9. Piper diagram with results of chemical analyses of groundwater and surface waters 
The location of points on the Piper diagram (Fig. 9) confirms areas of presence of genetically different waters: natural, saline, transitional (natural and saline waters mixing with each other), as well as waters affected by anthropopression. In the case of water from the Upper Jurassic aquifer, the difference between natural water $(F)$, $(\mathrm{G})$ and saline water $(\mathrm{B}),(\mathrm{H})$ is very clear - the points are groupped in two zones located on the opposing sides of every chart (E side, N-W side). Wells from deep Quaternary formation (D), (E) are grouped between saline and natural water from Upper Jurassic aquifer which indicates inflow of both natural and saline waters to them. The water in the pond (I) is also influenced by geogenical salinity - however, on a slightly greater scale than it is in the context of Quaternary wells. A similar example of salinization of surface waters was presented by Drwal \& Borowiak (2000).

Using Ogilvy method (Kiełczawa 2000), a chart showing the process of water mixing in selected wells and piezometers is shown in Figure 10. The rate of determination factor $\left(R^{2}\right)$ close to unity signifies very high correlation between the mineralization of water and the content of ions.

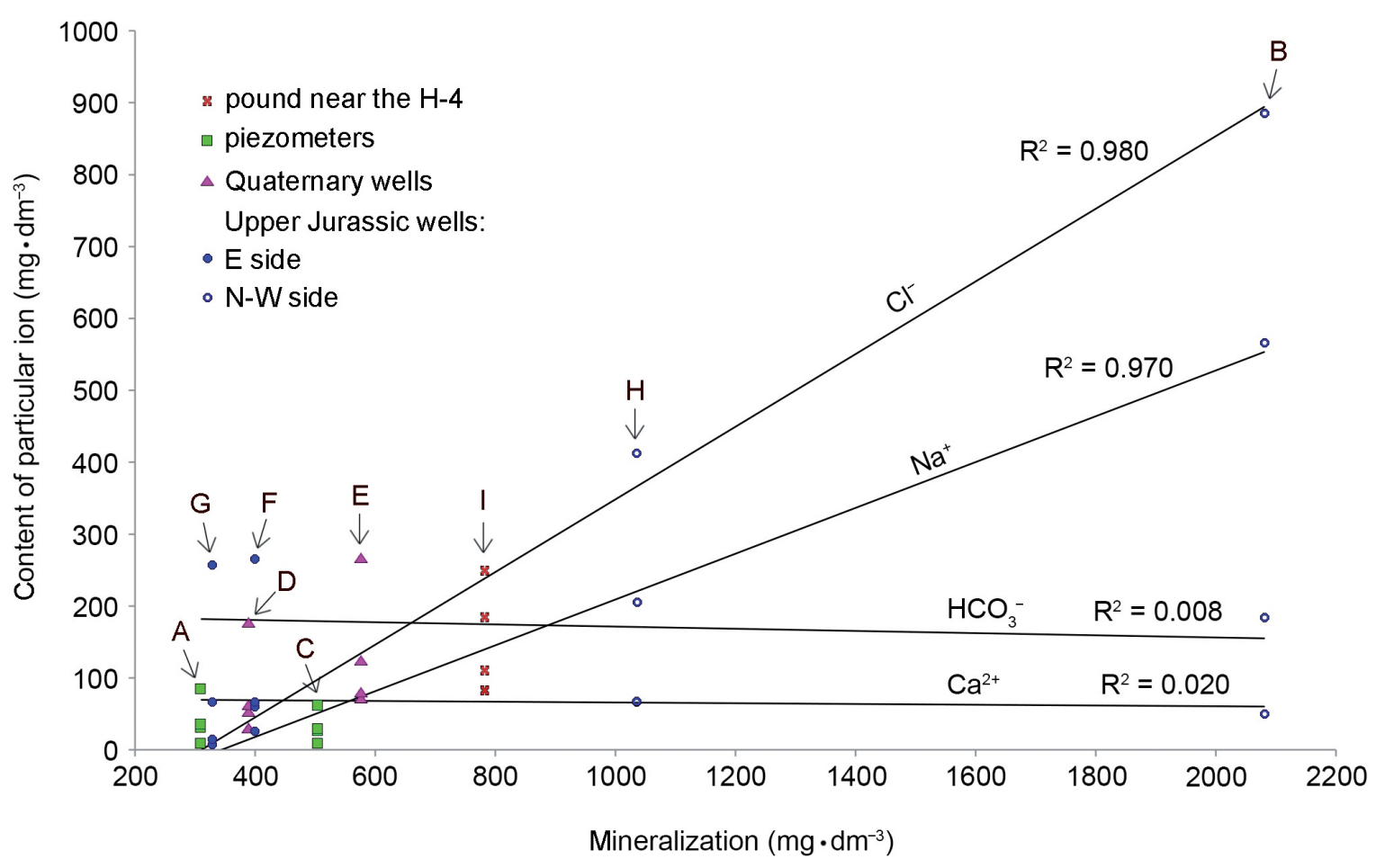

Data coming from selected objects, due to reference of charactrized ions to general mineralization, are arranged vertically Each point of collection arranged vertically is marked with a symbol coming from Figure 2, Table 3 and Table 5.

Fig. 10. Ogilvy chart showing the mixing of water in the area of Rogóźno salt dome

\section{CONCLUSIONS}

The research and analysis of surface water and groundwater show the following:

1. Rogóźno saline structure is not completely isolated from surrounding waters. Tectonic, saline, glaciotectonic and karst processes influence the entire complicated system of groundwater circulation.
2. The salt dome is located along the groundwater flow direction of Upper Jurassic formation in the regional drainage zone. It is supported by the completely different ion composition of water on opposite sides of the diapir.

3. The pond (I) and wells (D) and (E) are located within the area of increased SEC values which surrounds the salt dome. A mixing of mineralized geogenical waters and waters from 
shallow aquifers is present within Quaternary formation. These areas are influenced by saline water from around the salt dome.

4. The increased SEC in surface waters is present behind the northern border of the dome. The influence of the salt dome on surface water is expressed in high values of SEC and concentration of $\mathrm{Cl}^{-}$and $\mathrm{Na}^{+}$in the Dezerta River.

5. The Moszczenica River is influenced by saline waters either through tributaries (the Dezerta River) or saline waters in ditches in the area of Władysławów and Lorenki.

6. Anthropogenic influence is reflected in anomalies of physico-chemical parameters of groundwater observed in piezometers.

The authors would like to thank the Reviewers: Marek Matyjasik, Ph.D. and Dorota Porowska, Ph.D. for their suggestions which helped us to improve the manuscript.

\section{REFERENCES}

Bierkowska M. \& Błaszczyk J., 1989. Objaśnienia do Mapy hydrogeologicznej Polski w skali 1:200 000. Państwowy Instytut Geologiczny, Warszawa.

CBDH (Centralna Baza Danych Hydrogeologicznych, System Przetwarzania Danych Państwowej Służby Hydrogeologicznej), 2014. Państwowy Instytut Geologiczny - Państwowy Instytut Badawczy, Warszawa. [on-line:] http:// spdpsh.pgi.gov.pl/PSHv7/ [access: 14 February 2014].

Czapowski G., Surowce chemiczne. Sole kamienne i sole potasowo-magnezowe. Rogóźno. Państwowy Instytut Geologiczny - Państwowy Instytut Badawczy, Zakład Geologii Gospodarczej. [on-line:] http://surowce-chemiczne.pgi. gov.pl/sole_Rogozno.htm [access: 13.06.2016].

Czapowski G. \& Bukowski K., 2009. Złoża soli w Polsce - stan aktualny i perspektywy zagospodarowania. Przeglad Geologiczny, 57, 9, 798-811.

Czapowski G. \& Bukowski K., 2012. Salt resources in Poland at the beginning of the 21 st century. Geology, Geophysics \& Environment, 38, 2, 189-208.

Czarnecka H. (red.), 2005. Atlas podziatu hydrograficznego Polski. Cz. 1, Mapy w skali 1:200 000. Atlasy Instytutu Meteorologii i Gospodarki Wodnej, Instytut Meteorologii i Gospodarki Wodnej, Warszawa.

Czerwiński Z., 1996. Zasolenie wód i gleb na terenie Kujaw. Roczniki Gleboznawcze, 47, 3/4, 131-143.

Dokumentacja hydrogeologiczna określająca warunki hydrogeologiczne w związku z projektowaniem stacji dystrybucji paliw płynnych na dz. nr 127/1 w Rogóźnie. Archiwum Urzędu Marszałkowskiego Województwa Łódzkiego (dok. 1068), 2002 [unpublished].
Drwal J. \& Borowiak M., 2000. Chemizm wód powierzchniowych w strefie kontaktu lądu i morza. [in:] Burchard J. (eds.), Stan i antropogeniczne zmiany jakości wód w Polsce, Wydawnictwo Uniwersytetu Łódzkiego, Łódź, 91-100.

Dylik J., 1948. Rozwój osadnictwa w okolicach Łodzi. Acta Geographica Universitatis Lodziensis, 2, Łódzkie Towarzystwo Naukowe, Łódź.

Gołębiowska K., Niespodziewany A. \& Reczek T., 1994. Wskazówki metodyczne do projektowania regionalnego monitoringu wód powierzchniowych plynących. Biblioteka Monitoringu Środowiska, Państwowa Inspekcja Ochrony Środowiska, Warszawa.

Górecki M., 2015. Chlorki jako wskaźnik geogenicznego zasolenia wód powierzchniowych i gruntowych na obszarze wysadu solnego Rogóźno [M.Sc. thesis]. Repozytorium Uniwersytetu Łódzkiego, Łódź, [on-line:] http://dspace.uni.lodz. pl:8080/xmlui/handle/11089/16858 [access: 13.06.2016].

Górski J., 2001. Propozycja oceny antropogenicznego zanieczyszczenia wód podziemnych na podstawie wybranych wskaźników hydrochemicznych. [in:] Bocheńska T. \& Staśko S. (red.), Wspótczesne problemy hydrogeologii. T. 10, cz. 1, "Sudety", Wrocław, 309-313.

Hounslow A.W., 1995. Waret Quality Data. Analysis and Interpretation. Lewis Publishers, New York.

Hulisz P., 2007a. Wybrane aspekty badań gleb zasolonych w Polsce. Stowarzyszenie Oświatowców Polskich, Toruń.

Hulisz P., 2007b. Propozycje systematyki gleb zasolonych występujących w Polsce. Roczniki Gleboznawcze, 58, 1/2, 121-129.

Jaworski A., 1962. Aragonit w utworach czapy wysadu solnego w Rogóźnie koło Łodzi. Przegląd Geologiczny, 10, 11, 592-595.

Jaworski A., 1964. Powierzchniowe przejawy zasolenia na obszarze wysadu solnego w Rogóźnie koło Łodzi. Przegląd Geologiczny, 12, 3, 148-149.

Jodłowski A., 1977. Badania archeologiczne nad początkami eksploatacji soli w Polsce środkowej. Sprawozdania Archeologiczne, 29, 179-187.

Jokiel P., 2004. Zasoby wodne Środkowej Polski na progu XXI wieku. Wydawnictwo Uniwersytetu Łódzkiego, Łódź.

Kamiński J., 1993. Późnoplejstoceńska i holoceńska transformacja doliny Moszczenicy jako rezultat zmian środowiska naturalnego oraz działalności człowieka. Acta Geographica Lodziensia, 64, Łódzkie Towarzystwo Naukowe, Łódź.

Kiełczawa B., 2000. Zmienność mineralizacji wód górnokredowych Gorzanowa. Przegląd Geologiczny, 48, 12, 1195-1199.

Klatkowa H., 1993. Objaśnienia do Szczegółowej mapy geologicznej w skali 1:50 000. Arkusz Zgierz. Państwowy Instytut Geologiczny, Warszawa.

Kolago C., 1965. Perspektywy balneologiczne Łodzi. Przegląd Geologiczny, 13, 8, 350.

Kucharski L., 2009. Naturalna i półnaturalna roślinność nieleśna. [in:] Kurowski J.K. (red.), Szata roślinna Polski środkowej, Wydawnictwo EKO-GRAF, Łódź, 81-102.

Kwaterkiewicz A. \& Sadurski A., 1986. Problem genezy wód zmineralizowanych w sąsiedztwie Jeziora Żarnowieckiego. Annales Societatis Geologorum Poloniae, 56, 1-2, 163-177.

Macioszczyk A., 1987. System oceny jakości i stopnia zanieczyszczenia wód podziemnych eksploatowanych do celów pitnych. Przegląd Geologiczny, 35, 12, 628-636. 
Macioszczyk A. \& Dobrzyński D., 2002. Hydrogeochemia strefy aktywnej wymiany wód podziemnych. Wydawnictwo Naukowe PWN, Warszawa.

Maksymiuk Z., 2001. Wody. [in:] Liszewski S. (red.), Zarys monografii województwa łódzkiego, Łódzkie Towarzystwo Naukowe, Łódź, 60-68.

Marek S., 1957. Wstępne rozpoznanie stratygraficzne dolnej kredy w obszarze Rogóźna i Ozorkowa. Geological Quarterly, 1, 2, 247-258.

Mazurek M., 2000. Zmienność transportu materiału rozpuszczonego w zlewni Kłudy jako przejaw współczesnych procesów denudacji chemicznej (Pomorze Zachodnie). Wydawnictwo Naukowe UAM, Poznań.

Meszczyński J. \& Szczerbicka M., 2002. Objaśnienia do Mapy hydrogeologicznej Polski w skali 1:50 000. Arkusz Zgierz. Państwowy Instytut Geologiczny, Warszawa.

Mróz W. (red.), 2010. Monitoring siedlisk przyrodniczych: przewodnik metodyczny. Część 1. Biblioteka Monitoringu Środowiska, Główny Inspektorat Ochrony Środowiska, Warszawa.

Ocena stanu wód powierzchniowych, 2013. Wojewódzki Inspektorat Ochrony Środowiska w Łodzi.

Ochman D., Kawałko D., Kaszubkiewicz J. \& Jezierski P., 2011. Zawartość rozpuszczalnych kationów i anionów w wyciągach wodnych $\mathrm{z}$ gleb zasalanych wodami poflotacyjnymi infiltrującymi ze składowiska „Żelazny Most”. Ochrona Środowiska i Zasobów Naturalnych, 48, 266-275.

Pazdro Z. \& Kozerski B., 1990. Hydrogeologia ogólna. Wydawnictwa Geologiczne, Warszawa.

Prochazka K., 1970. Wpływ wysadowych struktur solnych Kłodawy $i$ Uścikowa na zasolenie skat nadkładu i wód studziennych. Prace Geologiczne - Polska Akademia Nauk. Oddział w Krakowie. Komisja Nauk Geologicznych, 62, Wydawnictwo Geologiczne, Warszawa.

Razowska L., 1999. Wskaźniki hydrochemiczne - mało przydatne czy niedoceniane. [in:] Krajewski S. \& Sadurski A. (red.), Wspótczesne problemy hydrogeologii. T. 9, Hydrogeologia na przełomie wieków, Warszawa-Kielce 15-17 września 1999, Państwowy Instytut Geologiczny, Warszawa, 307-313.

Singh P., Kumar Tiwari A. \& Kumar Singh P., 2014. Hydrochemical Characteristic and Quality Assessment of
Groundwater of Ranchi Township Area, Jharkhand, India. Current World Environment, 9, 3, 804-813.

Stelmaszczyk Z., 1972. Ogólna charakterystyka hydrogeologiczna obszaru Rogóźna. Archiwum Wydziału Geologii i Koncesji Geologicznych Urzędu Marszałkowskiego Województwa Łódzkiego, Łódź [M.Sc. thesis].

Szaniawski H., 1963. Wyjaśnienie stosunków wodnych w rejonie wysadu solnego Rogóźno. [in:] Dębski J., Podemski M. \& Szaniawski H. (red.), Dokumentacja geologiczna złoża soli kamiennej w wysadzie solnym Rogóźno, pow. Łęczyca, woj. Łódź, Państwowy Instytut Geologiczny, Warszawa, 38-51.

Szczepański W. (red.), 1995. Atlas posterunków wodowskazowych dla potrzeb państwowego monitoringu środowiska: posterunki wodowskazowe IMGW. Biblioteka Monitoringu Środowiska, Państwowa Inspekcja Ochrony Środowiska, Warszawa - Katowice.

Tarka R., 1992. Tektonika wybranych złóż soli w Polsce na podstawie badań mezostrukturalnych. Prace Państwowego Instytutu Geologicznego, 137, PIG, Warszawa.

Turkowska K., 2001. Budowa geologiczna i rzeźba terenu. [in:] Liszewski S. (red.), Zarys monografii województwa łódzkiego, Łódzkie Towarzystwo Naukowe, Łódź, 51-60.

Tynenski Z., Właziński Z., Adamska T. \& Lesiewicz A., 2007. Analiza możliwości wykorzystania zasobów wód geotermalnych i powierzchniowych oraz borowin w okolicy miejscowości Rogóźno dla potrzeb rozwoju turystyki, rekreacji i lecznictwa. Centrum Zrównoważonego Rozwoju, Łódź.

Winid B. \& Lewkiewicz-Małysa A., 2005. Mineralne wody lecznicze Iwonicza Zdroju w świetle badań wskaźników hydrochemicznych. Gospodarka Surowcami Mineralnymi, 21, 2, 49-67.

Witczak S., Kania J. \& Kmiecik E. (red.), 2013. Katalog wybranych fizycznych i chemicznych wskaźników zanieczyszczeń wód podziemnych i metod ich oznaczania. Biblioteka Monitoringu Środowiska, Inspekcja Ochrony Środowiska, Warszawa.

Zdechlik R. \& Kania J., 2003. Tło hydrogeochemiczne i rozkład stężeń jonów wskaźnikowych w rejonie złoża Bełchatów. [in:] Kozerski B. \& Jaworska-Szulc B. (red.), Wspótczesne problemy hydrogeologii. T. 11, cz. 2, Wydział Budownictwa Wodnego i Inżynierii Środowiska Politechniki Gdańskiej, Gdańsk, 327-334. 